\title{
Publisher Correction: journal of global entrepreneurship research, volume 10
}

\author{
Journal of Global Entrepreneurship Research
}

Published online: 17 June 2021

(C) The Author(s), under exclusive licence to Faculty of Entrepreneurship, University of Tehran 2021

\section{Publisher Correction: Xu et al. Journal of Global Entrepreneurship Research (2019) 9:71 https://doi.org/10.1186/s40497-019-0182-2}

An error occurred during the publication of two articles (Neubert \& Van Der Krogt, 2019; Xu et al., 2019) in Journal of Global Entrepreneurship Research. These articles were incorrectly published on 31 December 2019 in Volume
10. The articles have been updated so that they correctly appear in Volume 9. The article numbers have also been updated.

The updated information is shown in Table 1.

Table 1 Overview of incorrect and correct citation information

\begin{tabular}{lcc}
\hline DOI & Incorrect & Correct \\
\hline https://doi.org/10.1186/s40497-019-0182-2 & $\begin{array}{c}\text { Xu et al. Journal of Global Entrepreneurship } \\
\text { Research (2019) 10:2 }\end{array}$ & $\begin{array}{c}\text { Xu et al. Journal of Global Entrepreneurship } \\
\text { Research (2019) 9:71 }\end{array}$ \\
https://doi.org/10.1186/s40497-019-0195-x & $\begin{array}{c}\text { Neubert and Krogt Journal of Global } \\
\text { Entrepreneurship Research (2019) 10:1 }\end{array}$ & $\begin{array}{c}\text { Neubert and Krogt Journal of Global } \\
\text { Entrepreneurship Research (2019) 9:70 }\end{array}$ \\
\hline
\end{tabular}

The original articles have been updated. The publisher apologizes for the inconvenience caused to the authors and readers.

\section{References}

Neubert, M., \& Van Der Krogt, A. S. (2019). Decision-makers impact on the internationalization of high-technology firms in emerging

The online version of the original article can be found at https://doi.org/ 10.1186/s40497-019-0182-2

Journal of Global Entrepreneurship Research info@biomedcentral.com

1 London, UK markets. Journal of Global Entrepreneurship Research, 9, 70. https://doi.org/10.1186/s40497-019-0195-x.

Xu, L., Liu, M., \& Yao, H. (2019). Entrepreneurs' imprint: Survival and sustainable development of private aesthetic plastic surgery hospitals in China. Journal of Global Entrepreneurship Research, 9, 71. https://doi.org/10.1186/s40497-019-0182-2. 